\title{
CLINICAL, NEUROIMAGING AND EEG CORRELATIONS IN EPILEPTIC SYNDROME IN PATIENTS WITH A BRAIN TUMOR
}

\author{
Sh.B.Gafurov* \\ Tashkent Institute of Postgraduate Medical Education \\ Republican Scientific Center of Neurosurgery, Tashkent, Uzbekistan
}

\begin{abstract}
The results of the survey of 193 neuro-oncological patients with epileptic seizures are showed. The control group consisted of 97 patients with brain tumors without the development of epileptic seizures. It is found that in patients with the development of epileptic seizures as a first symptom of cerebral tumors predominated simple partial seizures. Early seizures occurred more frequently in lesions of the left hemisphere of the brain with the formation of focal abnormal EEG activity in the same hemisphere of the brain. Convulsive disorder prevailed in the localization of intracerebral tumors with caudal direction of its growth.
\end{abstract}

D espite the large number of studies the issue of epilepsy in patients with brain tumors remains to be one of the most actual health and social problems. This is due to the significant prevalence of the disease and its heavy disabling effects $[1,2,5]$.

Epileptic seizures in patients with brain tumors may occur in different periods of the disease development, often being the only manifestation of the tumor $[3,5]$. Depending on the time of seizures' occurrence in relation to tumor's symptoms appearance, seizures are divided on, precursors, early and late seizures [2, 4].

In connection with the development of neurooncology, which reached quite a rapid growth in the last few years, introduction of health care diagnosis and treatment standards in neurosurgery practice, the study of epileptic seizures within this patients' category is of great interest. Currently there is no generally accepted opinion about the timing of a certain seizures; according to different studies these terms are different that explains the variability in the frequency of early seizures.

Methods of investigation. A comprehensive survey of 193 patients with brain tumors and epileptic seizures development was conducted in order to identify clinical, functional, neuroimaging features of epileptic seizures in patients with neurooncological diseases.

The control group consisted of 97 patients with brain tumors of hemispheric localization, without epileptic seizures. These patients were comparable to the study group by age and clinical characteristics. The survey was conducted in departments of neurooncology and minimally invasive neuro*e-mail: shuhrat.1972@list.ru surgery, as well as at counseling clinic of Republican Scientific Center of Neurosurgery. Instrumental studies were performed during the interictal period. Neurological examination was performed by the standard technique with the evaluation of stroke severity scale of the National Institute of Health, USA - NIHSS. Visualization of brain structures was performed by means of magnetic resonance imaging (MRI) for the unit of intensity $1.5 \mathrm{~T}$ in the modes of T1, T2. The functional state of the cerebral hemispheres was assessed by electroencephalogram (EEG).

Results. It was revealed that in patients with tumors of the brain despite the overall prevalence of generalized tonic-clonic seizures $(53.6 \%)$ simple partial seizures $(43.6 \%)$ occurred more frequently in patients with early seizures.

The distinctive development of neurological deficit was revealed, especially motor disorders. Rough neurological deficit in NIHSS score was observed in patients with early seizures versus patients without seizures. Probably it had place due to the neurotransmitter blocks during epileptic activity appearance. Regression of neurologic deficits at the time of hospital discharge was more pronounced in patients without seizures.

Focal pathological EEG activity recorded in $97.7 \%$ of cases in patients suffering from epilepsy seizures, with advantage in the temporal $(43.5 \%)$ and parietal $(36.6 \%)$ regions compared with the other sites. Left-sided localization of focal activity was prevalent $(57.6 \%)$.

It was revealed that the highest frequency $(55.7 \%)$ of seizures ratio and clinically relevant pathologic area was observed in patients with 
epileptic seizures that have arisen as a primary symptom of the neoplasm.

Similar performance was observed in the ratio of seizures semiotics and focal slow wave and epileptiform EEG activity: if in a patient with epileptic seizures as a primary attribute of brain tumor clinical picture corresponded to the localization of focal activity and was recorded in $87 \%$ of cases, in the group of patients with seizures appearance after the accession of other symptoms - only in $32 \%$.

According to our observations, the attacks were more frequent in neurooncological patients with left-hemispheric location of the tumor $(51.5 \%)$ compared with patients with right hemispheric $(35.9 \%)$ and median tumor location $(12.6 \%)$.

Analysis of brain MRI revealed the predominance of intracerebral tumor localization in

\section{LITERATURE}

1. Carlov V.A. Epilepsy as a clinical and neurophysiological problem / Carlov V.A/ / Journal. Neurology and Psychiatry named after S.S. Korsakov. 2000. - № 9. - S. 7-15.

2. Lyubivaya M.A. Continued growth and recurrence of supratentorial brain tumors (clinical features, diagnosis, surgical treatment, and outcomes) / M.A. Lyubivaya.Nizhny Novgorod, 1993.-213p.

3. Savchenko Y.N. Epilepsy. Neurosurgical correction in treatment of disease / I.N. Savchenko, A. Y. Savchenko. Omsk, 2007. - 427p. patients with epilepsy (56\%) compared with control group (38.2\%). In assessing the MRI dynamics features of neoplastic growth attracted attention: patients with seizures showed a trend toward increased tumor growth and ischemia in the caudal direction, whereas in patients without seizures had a tendency to the formation of the ischemic focus in the rostral direction.

Conclusions. Thus, in patients with the epileptic seizures simple partial seizures predominated as a first symptom of cerebral tumors. Early seizures occurred more frequently in patients with tumors of the left hemisphere with the formation of the EEG focal pathological activity in the same hemisphere. The prevalence of intracerebral tumor localization with a caudal direction of its formation abnormality was revealed.

4. Stepanov I.N. On the question of surgical treatment of patients with latent tumors of temporal lobe suffering from epilepsy / I.N.Stepanov, A.Y.Savchenko / / Proceedings of the scientific conference, Omsk, 2000. - S. pp302-304.

5. Hauser, W. A. Remission, intractability, mortality, and comorbidity of epilepsy / W. A. Hauser, D. C. Hesdorffer / / The treatment of epilepsy: principles andpractice / Ed. by E. Wyllie. Philadelphia-: Lippincott Williams \& Wilkins, 2001. - P. 139-145.

\title{
PЕЗЮМЕ
}

\section{КЛИНИКО-НЕЙРОВИЗУАЛИЗАЦИОННЫЕ И ЭЛЕКТРОЭНЦЕФАЛОГРАФИЧЕСКИЕ СООТНОШЕНИЯ ПРИ ЭПИЛЕПТИЧЕСКОМ СИНДРОМЕ У БОЛЬНЫХ С ОПУХОЛЬЮ ГОЛОВНОГО МОЗГА}

\author{
Ш.Б.Гафуров \\ Ташкентский институт усовершенствования врачей, Ташкент; \\ Республиканский научный центр нейрохирургии, Ташкент
}

\begin{abstract}
Представлены результаты обследования 193 нейроонкологических больных с эпилептическими припадками. Контрольную группу составили 97 пациентов с опухолями головного мозга без развития эпилептических припадков. Установлено, что у больных с развитием эпилептических приступов в качестве первого симптома новообразования головного мозга преобладали простые парциальные приступы. Ранние эпилептические припадки чаще развивались при поражении левого полушария головного мозга с формированием на ЭЭГ очаговой патологической активности в том же полушарии головного мозга. Судорожный синдром превалировал при внутримозговой локализации новообразования с каудальной направленностью его роста.
\end{abstract}




\title{
XÜLASə
}

\section{BAŞ BEYININ ŞIŞi OLAN XəSTӘLӘRDӘ EPILEPTIK SINDROM ZAMANI KLINIIK-NEYROVIZUALIZASION VO ELEKTROENSEFALOQRAFIK KORRELYASIYYA}

\author{
Ş.B.Qafurov \\ Daşkənd həkimləri təkmilloşdirmə institutu, Daşkənd; \\ Respublika elmi neyrocarrahiyya markazi, Daşkand
}

Epileptik tutması olan 193 neyroonkoloji xəstənin müayinəsinin nəticələri təqdim edilmişdir. Kontrol qrupu epileptik tutmasız baş beynin şişi olan 97 pasiyent təşkil etmişdir. Təyin edilmişdir ki, epileptik tutmalar inkişaf edən xəstələrdə baş beynin yeni törəməsinin ilk simptomu qismində sadə parsial tutmalar üstünlük təşkil etmişdir. Erkən epileptik tutmalar cox vaxt baş beynin sol yarımkürəsinin zədələnmələri zamanı, elə həmin yarımkürədə də EEQ-də ocaqlı patoloji aktivliyin formalaşması ilə inkişaf edirdilər. Qıcolma sindromu törəmənin beyindaxili lokalizasiyası və kaudal istiqamətdə inkişafı zamanı üstünlük təşkil edirdi. 